\title{
Analysis of Illustrations used in Secondary Schools Physics Textbooks
}

\author{
Patriciah W. Wambugu, David G. Ngatia, Geoffrey N. Wanyoike \\ Department of Curriculum, Instruction \& Educational Management, Egerton University, Kenya
}

\begin{abstract}
The aim of this study is to analyse the illustrations in physics text books that are commonly used in Kenyan secondary. Illustrations in textbooks represent a very important element that helps to fulfil educational objectives in the teaching-learning process. The illustrations aid learning and assist the learners understand better what they read in the books enhancing learning outcomes. The illustrations considered in this study include diagrams, visual images and pictures. The four commonly physics textbooks used in Kenyan secondary schools were sampled. The illustrations in the books were analysed on how adequate they are in terms of; human activities, gender sensitivity, modern technology and depiction of portraits of physicists. Findings indicate that most illustrations in the studied physics textbooks do not depict human activity, there is gender stereotype in favour of boys and no illustrations of portraits of earlier physicists. Physics is a practical subject that involves a lot of human activity and it is important that the concepts illustrated in the textbooks depict human activity, be gender balanced and reflect the current technology. Physics textbooks used for teaching students need to be periodically revised with the view to make them have adequate learning activities.
\end{abstract}

Keywords: Illustrations, physics textbooks, secondary schools

\section{INTRODUCTION}

Textbooks serve as an important tool in the teaching-learning process and acts as the guide for teachers and students. Textbooks are a good source of information for teaching which influence teachers' practice and also a valuable resource for students to study the content taught in school. (Nwafor \& Umoke, 2016; Gichura, 2003; Abimbola \& Baba, 1996). Textbooks provide structure and order in the teaching and learning process as they have a major role of transmitting information about reality that is impossible or hard to be directly observed. In addition, textbooks are useful instruments whose purpose is to facilitate the work of the teacher on a daily basis and to give students stability, confidence and create real interest for subjects (Triyoga, 2010; Johansson, 2006). Textbooks must represent the concepts in science in such a way that learners are able to master the content. However, learners can only learn from textbooks if they can read and understand them (Hsu \& Yang, 2007). According to Areo (2001) a good text book should: Cover the prescribed syllabus adequately; be arranged in a logical Sequence; be clearly laid out and not be clumsy; be lucid; contain adequate and appropriate, well labelled functional illustrations; provide for adequate practice and revision exercises; be of durable quality; be current in factual and informative materials; not contain genderrole stereotypes. A good textbook must therefore contain adequate and appropriate, well labelled functional illustrations, that match with the words of the book. It makes the textbook content livelier and more interesting and also offers to the student an opportunity for identification (Potter \& Rosser, 1992).

Illustrations in physics textbooks aid learning and assist the learners understand better what they read. The illustrations included in the textbooks play an important role in the learning process as they facilitate the understanding of the scientific content and bring about enhancement in learning outcomes. Some textbooks have however been found to have illustrations which are inadequate in supporting the learning process. This study aimed to analyse the illustrations in four commonly used Secondary School Physics text books in Kenya (Appendix 1) with an aim of determining how adequate they are in terms of human activities, gender sensitivity, modern technology and depiction of portraits of physicists.

\section{Purpose of The Study}

The purpose of this study was to determine the adequacy and appropriateness of the illustrations in the physics text books used in Kenyan secondary schools 


\section{OBJECTIVES OF THE STUDY}

The objectives of the study were to:

1. Establish the number of human activities in the illustrations used in secondary school Physics textbooks.

2. investigate the gender sensitivity in the illustrations used in the secondary school Physics text books

3. investigate the adequacy of modern technology in the illustrations used in the secondary school Physics text books

4. investigate the presence of portraits of the physicists in the illustrations used in the secondary school Physics text books

\section{RESEARCH QUESTIONS}

The study sought to answer the following research questions:

1. How many illusrations in the secondary school physics textbooks depict human activity?

2. How many illustrations in the secondary school physics textbooks can be recognizedas masculine or feminine?

3. How many illustrations in the secondary school physics textbooks depict modern technology?

4. How many portraits of physicists are included in the illustrations in the secondary school physics textbooks.

\section{MeThodology}

The research design used in this study was ex-post facto. This is because inferences on relations among variables were made without direct manipulation of independent and dependent variables (Gall, Borg \& Gall, 2007). The instrument used for the study were the four commonly used Secondary School physics textbooks in Kenya, for form one to four (Appendix1). A total of 5105 illustrations were identified in all the textbooks. The illustrations considered included diagrams, visual images and pictures. These illustrations were analysed against the following variables: Human activity, gender sensitivity, modern technology and presence of portraits of physicists. The data collected was analysed using descriptive statistics in form of simple percentages and graphical representations.

\section{RESUlts And Discussion}

Table1. Summary of Illustrations Showing Human Activity in Selected Secondary School Physics Textbooks

\begin{tabular}{|l|l|l|l|}
\hline Textbook & Human Activity & Non-human Activity & Total \\
\hline 1 & $104(7.5 \%)$ & $1280(92.5 \%)$ & 1384 \\
\hline 2 & $123(8.2 \%)$ & $1372(91.8 \%)$ & 1495 \\
\hline 3 & $83(6.7 \%)$ & $1150 \quad(93.3 \%)$ & 1233 \\
\hline 4 & $62(6.2 \%)$ & $931 \quad(93.8 \%)$ & 993 \\
\hline Total & $372(7.3 \%)$ & $4733(92.7 \%)$ & 5105 \\
\hline
\end{tabular}

It is evident from Table 1, that most illustrations in the studied physics textbooks do not depict any human activity. Out of the total 5105 illustrations in all the four physics textbooks in all the classes considered, only 372 contain human activity which translates to only $7.3 \%$ of all illustrations. Physics is a practical subject that involves a lot of human activity and it is important that the concepts illustrated in the textbooks depict human activity. Illustrations depicting human is minimal in the selected secondary school physics textbooks (Figure 1)

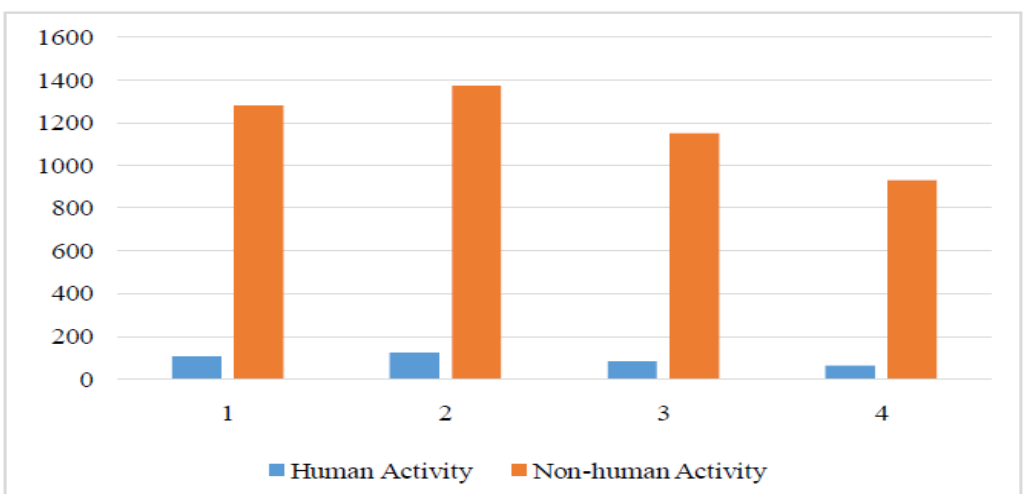

Figure1. Graphical Representation of the Illustrations in the Selected Secondary School Physics Textbooks Depicting Human and Non- Human Activities 
Analysis of Illustrations used in Secondary Schools Physics Textbooks

Further illustrations were classified according to whether they depicted human activity by gender (Table 2)

Table2. Summary of Illustrations Showing Human Activity by Gender in Selected Physics Textbooks

\begin{tabular}{|c|c|c|c|c|c|}
\hline Text Book & 1 & 2 & 3 & 4 & Total \\
\hline Male & 18 & 26 & 6 & 1 & 51 \\
\hline Female & 3 & 7 & 6 & 5 & 21 \\
\hline Both & 2 & 8 & 3 & 3 & 16 \\
\hline Unidentifiable & 81 & 82 & 68 & 53 & 284 \\
\hline Total & 104 & 123 & 83 & 62 & 372 \\
\hline
\end{tabular}

The four secondary school physics textbooks studied show gender bias in the illustration as shown in Table 2. In all textbooks, illustrations showing men or boys performing an activity were more predominant in comparison with illustrations showing women or girls undertaking an activity except in 3 and 4 textbooks where female illustrations were higher or equal to male illustrations. From the Table 2, only 21 illustrations depict female figures in contrast to 51 illustrations that depicts male figures and 16 illustrations where both male and female figures are depicted. The illustrations in most textbooks further shows a gender stereotype in favour of boys. For example, in Book three of textbook 3, a man is shown lifting a load while a lady is depicted using an inclined plane to lift the same load. Another illustration in book two of textbook 2 shows a boy lifting two girls in a see-saw. Table 2 further indicate that a larger proportion of illustrations constituting $76 \%$ in all textbooks are hard to identify whether they are male or female figures. Biased textbooks and instructional methods and stereotypical views of physics being a male domain make the girls to look at physics as a male dominated field which they cannot identify with and consequently have a negative attitude towards physics (Sovič\&Husa, 2015). Figure 2 shows the illustrations in the selected text books by gender.

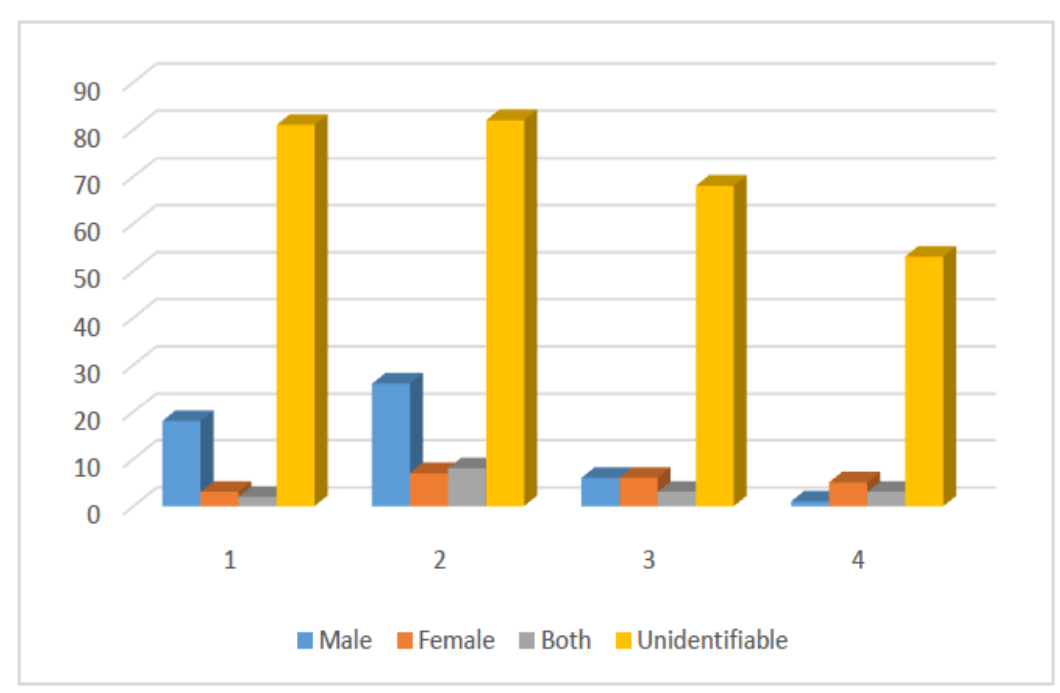

Figure2. Illustrations in the Selected Secondary School Physics Textbooks by Gender

The study investigated the adequacy of modern technology in the illustrations used in the secondary school Physics text books the findings are shown in Table 3.

Table3. Summary of Illustrations Depicting Modern and Old Technology in Selected Physics Textbooks

\begin{tabular}{|l|l|l|l|}
\hline Textbook & Old technology & Modern technology & Total \\
\hline 1 & 11 & 3 & 14 \\
\hline 2 & 4 & 1 & 5 \\
\hline 3 & 9 & 2 & 11 \\
\hline 4 & 6 & 0 & 6 \\
\hline Total & $27(75 \%)$ & $9(25 \%)$ & 36 \\
\hline
\end{tabular}

The results in Table 3 indicate that most of the secondary school physics textbooks considered in the study had illustrations that depicted old technology as compared to new the new technology. The illustrations depicting old technology constituted $75 \%$. For example, the form one issue of textbook 3 shows an illustration of the old technology camera while form 2 issue of textbook 1 depicts an old technology of the telephone earpiece and mouth piece. Figure 3 is a graphical representation of the Illustrations depicting Old and modern technology in selected secondary school textbooks. 


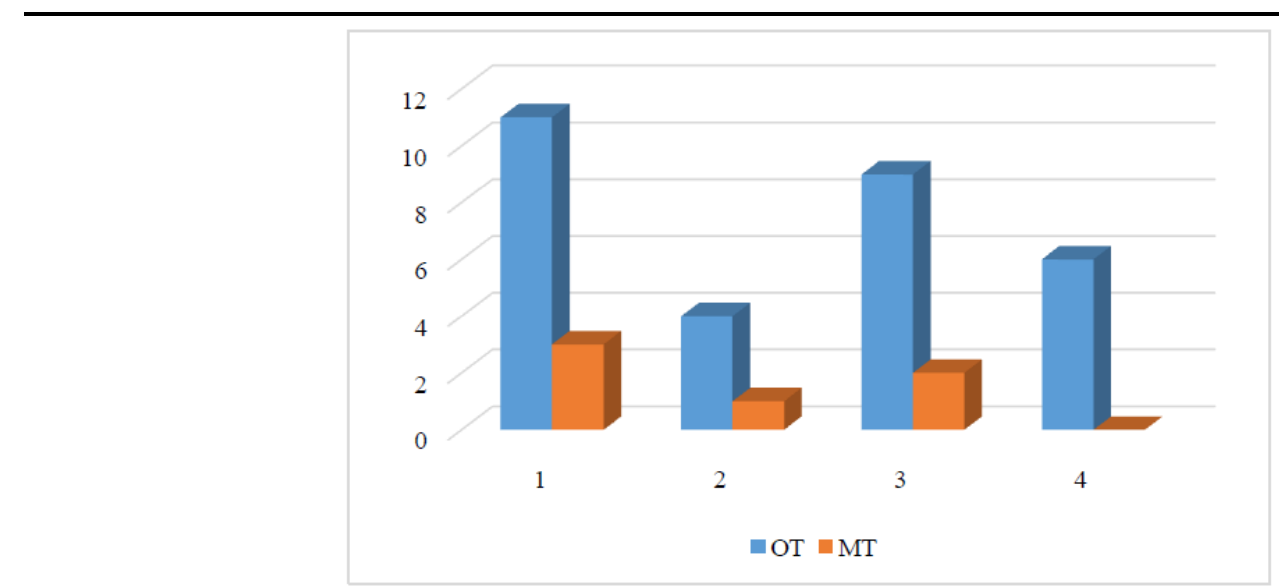

Figure3. Illustrations Depicting Old Technology (OT) and Modern Technology (MT) in Selected Secondary School Physics Textbooks

In all physics textbooks studied, there were no illustrations of portraits of the earlier physicist. The student may therefore not link the concepts, principles and laws taught in physics with the persons who discovered them.

\section{CONCluSiON}

Illustrations are an important component of instructional textbooks which attracts learners' attention, create interest and motivate them to read instructional materials as well as enhancing their comprehension and memory of concepts. However, the results of the findings of the study, indicate that to an extent the illustrations in the secondary school physics textbooks are inadequate with regard to human activities, gender balance, modern technology and portraits of physicist. The textbooks indicate illustrations without human activity for example the illustration showing rectilinear propagation of light only an eye is shown. The gender stereotypes portray boys as generally brave, strong and adventurous, girls on the other hand are shown as shy and timid. Aniche (1998) contend that school textbooks should not contain gender stereotypes, which could have negative effects on the learners' self-image, ability and future aspirations.

\section{RECOMMENDATIONS}

The people involved in book production including writers, editors, illustrators and publishers should ensure that more care should be put on the illustrations they include so that textbooks become more useful teaching and learning resources. Besides, teachers and curriculum developers should be made aware of the role of illustrations in physics in order to select the most appropriate textbooks for students.

\section{REFERENCES}

Abimbola, I.O., \& Baba, S. (1996). Misconceptions \& alternative conceptions in science textbooks: The role of teachers as filters. The American Biology Teacher, 58, 14-19.

Aniche O. (1998). Gender Issues in Education and State of Education in Nigeria Lagos, UNESCO

Areo, A. (2001). An Overview of Sex-Rote and Gender-Role Issues in Book Publishing- a paper presented at UNESCO/NERDC Gender Sensitive Approach to Textbook, Development Workshop held in Kano

Gall M. D, Borg J. P. \& Gall W. R. (2007). Educational Research: An Introduction (6 ${ }^{\text {th }}$ ed.) Allyn and Bacon. Boston

Gichura, S. (2003). The turning point: free primary education in Kenya. Network for International Policies and Cooperation in Education and Training. Norrag News, p. 37-41.

Hsu, P. \& Yang, W.G. (2007). Print and image integration of Science texts and reading comprehension: A systematic function linguistics perspective, International Journal of Science and Mathematics Education, 5, 639-659.

Johansson, M. (2006). Teaching Mathematics with Textbooks: A classroom and curricular perspectives. Lulea University of Technology: Doctoral Thesis (Unpublished).

Nwafor C. E. \&Umoke C. C. (2016).Evaluation of Some Approved Basic Science and Technology Textbooks in use in Junior Secondary Schools in Nigeria. Journal of Education and Practice7, (14) $69-78$ 
Potter E \& Rosser S. (1992). Factor in Life Sciences textbooks that may deter girls' interest in science, Journal of Research inScience Teaching 29, 669

Sovič A. \&Husa V. (2015). Gender Stereotype Analysis of the Textbooks for Young Learners. Social and Behavioral Sciences, 186 (2015) 495 - 501

Triyoga, A. (2010). Some Hindrances in using Ready-made Textbooks. Post Graduate Program. English Education Department. Ahmed Dahlan University.

\section{APPENDIX 1: List of Analysed Textbooks}

Minishi O., Muni E., Omolo H.\& Mwangasha G.(2016), Secondary Physics Students Book One, Kenya Literature Bureau. Nairobi

Minishi,O., Muni E.,Okumu O., Mutai P., Omolo H., Munyeke F., Mwangasha G.\& Willis B. (2009). Secondary Physics Students Book Two, Kenya Literature Bureau. Nairobi

Minishi O., Muni E., Okumu O., Mutai P., OmoloH.,Munyeke F.\&Mwangasha G. (2015), Secondary Physics Students Book Three, Kenya Literature Bureau. Nairobi

Minishi,O., Muni E., Okumu O., Mutai P., Omolo H., Munyeke F., Mwangasha G.\& Willis B. (2013), Secondary Physics Students Book Four, Kenya Literature Bureau. Nairobi

Rabari J.A (2003), Foundation Physics Students' Book for Form One, Jomo Kenyatta Foundation. Nairobi

Rabari J.A (2004), Foundation Physics Students' Book for Form Two, Jomo Kenyatta Foundation. Nairobi

Rabari J.A (2004), Foundation Physics Students'Book for Form Three, Jomo Kenyatta Foundation. Nairobi

Rabari J.A (2007), Foundation Physics Students' Book for Form Four, Jomo Kenyatta Foundation. Nairobi

Balaraman K. \&Kariuki C. (2003), Longhorn Secondary Physics Form 1, Longhorn Publishers Kenya Ltd, Nairobi

Balaraman K.\&Kariuki C. (2003), Longhorn Secondary Physics Form 2, Longhorn Publishers Kenya Ltd, Nairobi

Balaraman K., Kariuki C. \& Kanga P. (2005), Longhorn Secondary Physics Form 3, Longhorn Publishers Kenya Ltd, Nairobi

Balaraman K. \&Kariuki C. (2005), Longhorn Secondary Physics Form 4, Longhorn Publishers Kenya Ltd, Nairobi

Muriithi W. \&Ringeera D. (2003), Comprehensive Secondary Physics Form 1, Oxford University Press East Africa Ltd, Nairobi

Muriithi W. \&Ringeera D. (2008), Comprehensive Secondary Physics Form 2, Oxford University Press East Africa Ltd, Nairobi

Muriithi W. \&Ringeera D. (2004), Comprehensive Secondary Physics Form 3, Oxford University Press East Africa Ltd, Nairobi

Muriithi W. \&Ringeera D. (2010), Comprehensive Secondary Physics Form 4, Oxford University Press East Africa Ltd, Nairobi 